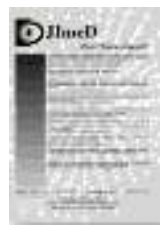

Jurnal Imejing Diagnostik (JImeD) 6 (2020) 96-102

\title{
Analisis Dosis Paparan Radiasi Pada General X-Ray II Di Instalasi Radiologi Rumah Sakit Muhammadiyah Semarang
}

\author{
Ida Septiyanti ${ }^{1}$, M. Ardhi Khalif ${ }^{2}$, Edi Daenuri Anwar ${ }^{3}$ \\ 123 Universitas Islam Negeri Walisongo Semarang, Indonesia \\ Corresponding author: Ida Septiyanti \\ E-mail: idaseptiyanti082@gmail.com
}

Received: June $18^{\text {th }}, 2020$; Revised: June $20^{\text {th }}, 2020$; Accepted: June $30^{\text {th }}, 2020$

\begin{abstract}
Background: This study analyzes the Radiation Dose of the General X-ray Radiology Installation at Roemani Hospital Muhammadiyah Semarang to determine the dose received by the radiographer, the community around the room and to know the value of the effectiveness of radiation protection and to determine the pattern of radiation exposure distribution in the general X-ray radiology installation room II.

Methods: Measurements were taken during general X-ray exposure and without exposure using a 451P ion chamber survey. Measurement of dose data received by the radiographer and the community around the room is taken at the point of the operator's room, service room, waiting room. As for the measurement of the effectiveness of radiation protection taken at the point in the operator's room and the general X-ray II and the radiation distribution pattern taken at points $\mathrm{A}, \mathrm{B}, \mathrm{C}, \mathrm{D}$ and $\mathrm{E}$ with a distance of $40 \mathrm{~cm}, 80 \mathrm{~cm}$ and $120 \mathrm{~cm}$ in the room general X-ray II.

Result: The result of measurements in the operator room are $0.0354 \mu \mathrm{Sv}$ / hour, waiting rooms with a distance of $3.5 \mathrm{~m}$ at $0.0146 \mu \mathrm{Sv} /$ hour, in the service room and waiting room with a distance of $8 \mathrm{~m}$ at $0 \mu \mathrm{Sv} /$ hour. The value of the effectiveness of radiation protection in the operator station is $83.33 \%$ and the general X-ray II door is $84.09 \%$.

Conclusions: Based on the results of the data obtained the value of the dose received and the value of effectiveness is quite safe from excessive radiation exposure. The radiation distribution pattern, the farther the distance from the radiation source, the measured radiation exposure value will be lower.
\end{abstract}

Keywords: Radiation Dose; Radiation Exposure; Effectiveness of Radiation Protection; General X-ray

\section{Pemdahuluan}

Rumah sakit adalah sebuah institusi kesehatan yang penting dalam kehidupan. Di dalam rumah sakit terdiri dari berbagai macam unit yang menangani masalah-masalah kesehatan, meliputi diagnosa, terapi, perawatan, pembedahan dan lain-lainnya. Diagnosa adalah proses mengidentifikasi suatu penyakit dengan cara memeriksa gejala-gejala yang ada dalam tubuh pasien. Pada diagnosa rumah sakit memiliki berbagai macam alat di antaranya alat dalam bidang radiologi, misalnya CT-SCAN, MRI, Panoramic, PET SCAN, LINAX, USG, General Xray dan lain-lainnya.

General X-ray adalah pencitraan yang menggunakan radiasi untuk mengambil gambar bagian dalam dari tubuh seseorang yang terserang penyakit. Pemanfaatan citra hasil dari General X-ray dapat menguntungkan dibidang diagnosa karena dokter dapat mengetahui keadaan tubuh manusia tanpa melakukan pembedahan. Selain manfaat General X-ray juga memberikan dampak negatif bagi para pekerja, pasien dan masyarakat yang berada di lingkungan sekitar serta membawa resiko menginduksi kanker tambahan (Yuliati dan Akhadi, 2001; Raudhah, 2008). Oleh sebab itu setiap instalasi radiologi di setiap rumah sakit harus memperhatikan proteksi radiasi (IAEA, 2006; Martem dkk, 2015). Proteksi radiasi merupakan aspek yang sangat penting bagi pengendalian dampak negatif dari radiasi. Dampak negatif radiasi diterima oleh radiographer dan masyarakat sekitar yang berada di lingkungan sekitar ruang radiasi sesuai dengan dengan peraturan pemerintah Nomor 33 Tahun 2007 Surat keputusan 
kepala BAPETEN Nomor 01/Ka-Bapeten/V-99 Nilai batas dosis untuk pekerja radiasi $<50 \mathrm{mSv} /$ tahun sedangkan untuk masyarakat umum $<5 \mathrm{mSv} /$ tahun (BAPETEN, 2003).

Proteksi radiasi diperlukan untuk menyerap radiasi sehingga dapat mengurangi intensitas radiasi yang dipancarkan dan mengurangi penerimaan dosis radiasi oleh tubuh manusia. Apabila radiasi masuk kedalam proteksi radiasi, maka sebagian dari radiasi tersebut akan diserap oleh bahan. Semakin besar efektivitas proteksi radiasi suatu ruangan maka proteksi radiasi ruangan tersebut semakin baik dalam menyerap radiasi (Martem dkk, 2015). Penelitian ini sudah banyak diteliti, salah satunya Rudi dkk (2012) dalam mengukur paparan radiasi menggunakan surveymeter untuk mengetahui paparan radiasi pada tabung dan lingkungan Pesawat sinar-X Radiodiagnostik. Hasil penelitiannya nilai paparan tertinggi berada di atas tabung sinar- $X$ nilainya sebesar $0,153 \mathrm{mR} / \mathrm{jam}$, sedangkan nilai paparan radiasi yang berada disektar ruang sinar-X berada di ruang operator Computed Radiography (CO) sebesar $0,031 \mathrm{mR} / \mathrm{jam}$. Martem dkk (2015) dalam mengukur efektivitas proteksi radiasi, hasil penelitiannya nilai efektivitas proteksi radiasi pada penyinaran panoramik yaitu $99,33 \%$ dan pada penyinaran intraoral sebesar 99,83\%. Beberapa permasalahan tersebut mendasari peneliti untuk mengetahui paparan radiasi yang berada di lingkungan General X-ray II dan sekitarnya yaitu perlu adanya pengukuran paparan radiasi sinar-X untuk mengetahui nilai paparan radiasi yang diterima oleh pekerja dan masyarakat sekitar, hasil yang didapatkan dianalisis sesuai dengan nilai batas yang telah ditentukan oleh BAPETEN.

Radiasi adalah suatu pancaran energi yang melalui sebuah ruangan dalam bentuk panas, partikel atau gelombang elektromagnetik atau cahaya foton dari sumber radiasi (BATAN,n.d). Radiasi ini terbagi menjadi dua yaitu Radiasi Ion Non Pengion dan Radiasi Pengion. Radiasi Ion Non Pengion merupakan radiasi di mana sifatnya tidak dapat mengubah ion-ion yang dilaluinya dan tidak menyebabkan efek ionisasi apabila berinteraksi dengan materi. Sedangkan Radiasi Pengion merupakan radiasi dimana sifatnya dapat mengubah ion-ion yang dilaluinya dan menyebabkan efek ionisasi apabila berinteraksi dengan materi, bila mengenai makhluk hidup, maka sinar-X mampu merusak sel-sel hidup. Jika radiasi mengenai tubuh manusia, ada dua kemungkinan yang akan terjadi pada manusia yaitu berinteraksi dengan tubuh manusia atau hanya melewati saja. Jika radiasi berinteraksi dengan tubuh manusia maka radiasi dapat mengionisasi atom. Setiap terjadinya ionisasi tersebut radiasi akan kehilangan sebagain energinya.

Efek radiasi pada manusia

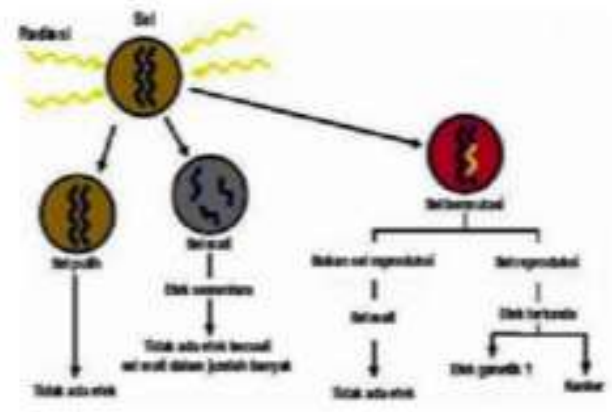

Gambar 1. Efek Radiasi bagi manusia

Untuk mengurangi resiko radiasi, diperlukan perisai radiasi atau proteksi radiasi yang dapat menyerap radiasi hingga memperkecil intensitas radiasi yang lolos dan dapat mengurangi penerimaan radiasi oleh tubuh manusia. Jika radiasi elektromagnetik masuk ke bahan perisai Io, maka sebagian radiasi akan diserap oleh bahan sehingga intensitas radiasi yang keluar dari bahan sebesar $I$. Jika bahan perisai memiliki ketebalan $\mathrm{x}$, maka radiasi yang keluar dari bahan perisai diformulasikan:

$$
I=I_{o} \cdot \mathrm{e}^{-\mu \mathrm{x}}
$$

Radiasi gelombang elektromagnetik dari suatu sumber titik bersifat simetri radial karena muka gelombangnya berbentuk permukaan bola. Diantara besaran yang diukur pada suatu radiasi elektromagnetik adalah intensitas radiasi. intensitas radiasi dari suatu gelombang elektromagnet bukan merupakan amplitudo dari gelombang elektromagnetik tersebut melainkan adalah kuadrat amplitudonya. Untuk radiasi dari suatu bahan radioaktif, di antara alat yang dapat digunakan untuk mengukur intensitas radiasinya adalah surveymeter. Berbeda dengan radiasi cahaya tampak, intensitas radiasi dari suatu bahan radioaktif akan meluruh secara eksponensial menurut persamaan peluruhan sebagai berikut (Akhadi,2000) :

$$
N_{t}=N_{o} e^{-\lambda t}
$$

Untuk muka gelombang yang berbentuk $\frac{1}{2}$ bola, secara prinsip kondisi tersebut dapat dibentuk dengan cara memberi "cover" penghalang di sekitar sumber radiasi sehingga radiasinya hanya dalam arah $\frac{1}{2}$ bola saja. Namun meskipun pada suatu sumber radioaktif 
diberi sebuah "cover" penghalang untuk menghasilkan suatu keluaran muka gelombang dalam bentuk tertentu, intensitas radiasinyatetap harus memenuhi persamaan peluruhan radiasi di atas.

General X-Ray

General X-ray adalah suatu alat rumah sakit yang digunakan untuk melakukan diagnosa medis dengan menggunakan sinar-X tanpa melakukan pembedahan. Sinar-X dipancarkan dari tabung kemudian diarahkan kebagian tubuh yang akan di diagnosa. Berkas sinar-X akan menembus bagian tubuh manusia dan ditangkap oleh film, sehingga gambar akan terbentuk dari bagian tubuh yang disinari (Sianturt dkk, 2017).

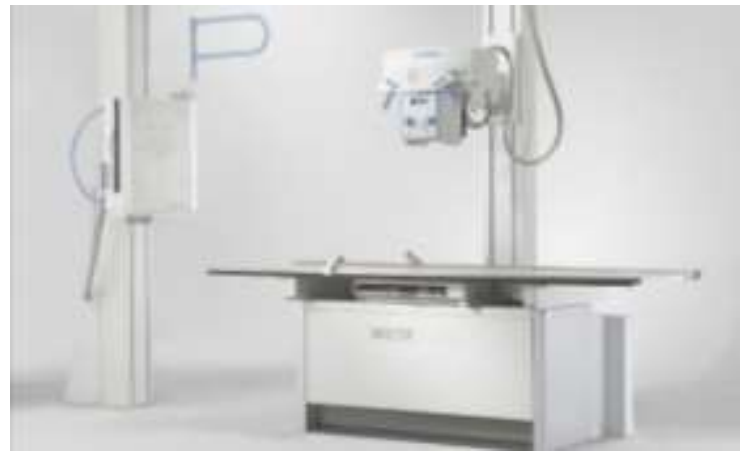

Gambar 2. General X-Ray

Nilai Batas Dosis

Nilai batas dosis berdasarkan rekomendasi IRCP No. 60 Tahun 1990 :

\begin{tabular}{|l|c|c|}
\hline \multirow{2}{*}{} & \multicolumn{2}{|c|}{ NILAI BATAS DOSIS (NBD) Untuk } \\
\cline { 2 - 3 } & Pekerja Radiasi & Publik \\
\hline Dosis Efektif & $\begin{array}{r}20 \mathrm{mSv} / \text { tahun rata }- \text { rata } \\
\text { selama } 5 \text { tahun }\end{array}$ & $1 \mathrm{mSv} /$ tahun \\
\hline Dosis ekivalen per tahun pada bagian: \\
\hline Lensa Mata & $150 \mathrm{mSv}$ & $15 \mathrm{mSv}$ \\
\hline Kulit Tubuh & $500 \mathrm{mSv}$ & $50 \mathrm{mSv}$ \\
\hline $\begin{array}{l}\text { Tangan dan } \\
\text { Kaki }\end{array}$ & $500 \mathrm{mSv}$ & $\begin{array}{c}\text { (tidak ada } \\
\text { rekomendasi) }\end{array}$ \\
\hline
\end{tabular}

Gambar 3. Nilai Batas Dosis

Interpolasi adalah proses pencarian dan perhitungan nilai suatu fungsi grafiknya melalui beberapa titik yang sudah diberikan. Titik-titik tersebut bisa berupa hasil eksperimen dalam sebuah percobaan maupun dari sebuah fungsi yang telah diketahui. Fungsi interpolasi yang sering digunakan dari sekelompok fungsi tertentu adalah fungsi polinomial (Sahid, 2005). Fungsi polinomial interpolasi biasanya mengarah untuk menyelesaikan permasalah yang mengarah ke fungsi spline, interpolasi cubic spline $S(x)$ adalah sebuah potongan fungsi polinomial kecil-kecil yang berderajat tiga (cubic) menghubungkan antara dua titik yang bersebelahan dengan ketentuan tertentu (supriyanto, 2006).

\section{Metode}

Sampel pada penelitian ini adalah titik-titik yang telah ditentukan pada instalasi radiologi. Untuk pengambilan data paparan radiasi di ukur pada ruang operator, ruang pelayanan, dan ruang tunggu pada titik biru yang dapat dilihat pada gambar 3.1 :

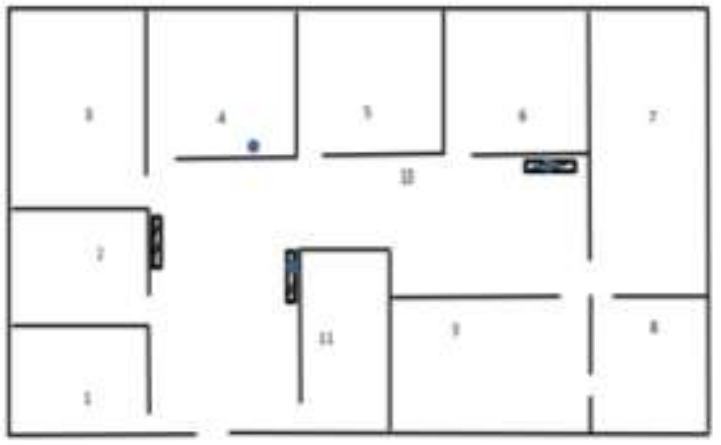

Gambar 4. Denah Ruang Instalasi Radiologi Keterangan :

1) Ruang Transit

2) Ruang ESWL

3) Ruang General X-ray I

4) Ruang Pelayanan Radiologi

5) Ruang USG

6) Ruang panoramic

7) Ruang CT-Scan

8) Ruang Operator

9) Ruang General X-ray II

10) Ruang Tunggu

11) WC dan Gudang

Untuk pengambilan data efektivitas proteksi radiasi, titik yang di ambil adalah ruang operator di luar ruang general X-ray II pada titik biru yang dapat dilihat pada gambar 3.2 : 


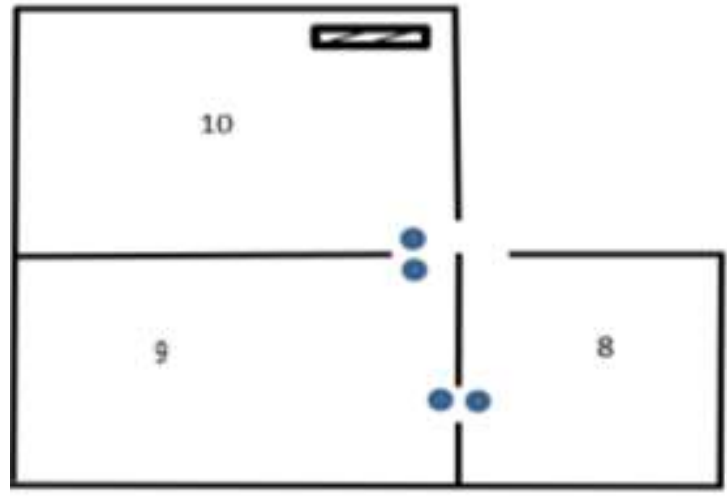

Gambar 5. Denah Ruang General X-ray II dan Ruang Operator

Keterangan :

8. Ruang Operator

9. Ruang General X-ray II

10. Ruang Tunggu

Untuk pengambilan data persebaran radiasi di ruang general X-ray dilakukan di 5 yaitu titik A, B, C ,D dan E. Dimana setiap titik diukur di 3 titik dengan jarak masing-masing $0.4 \mathrm{~m}, 0.8 \mathrm{~m}$, dan $1.2 \mathrm{~m}$ pada titik biru yang dapat dilihat pada gambar 3.3 :

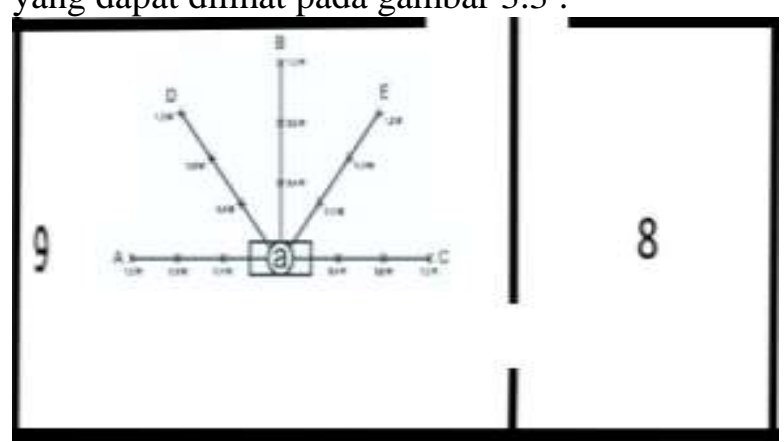

Gambar 6. Denah Ruang General X-ray beserta titik untuk sebaran radiasi

Keterangan :

8. Ruang Operator

9. Ruang General X-ray II

a. General X-ray

Setelah data didapatkan berupa dosis yang terukur pada Ion Chamber Surveymeter 451P, data dianalisis untuk nilai efektivitas proteksi radiasi menggunakan persamaan :

$$
\text { Efektifitas }(\%)=\frac{D_{0-} D_{a}}{D_{0}} \times 100 \%
$$

Setelah data diolah kemudian dilakukan verifikasi data menurut acuan paparan radiasi. Untuk pengukuran paparan radiasi general X-ray, tolok ukur tingkat paparan radiasi tidak boleh lebih dari 100 $\mathrm{mR} / \mathrm{jam}$. Tolok ukur paparan radiasi yang di tempati oleh pekerja radiasi tidak boleh melebihi $2,5 \mathrm{mR} / \mathrm{jam}$, sedangkan untuk masyarakat umum tidak boleh melebihi $0,25 \mathrm{mR} / \mathrm{jam}$.

\section{Hasil dan Pembahasan}

Penelitian ini menghasilkan nilai paparan radiasi yang ada di Instalasi Radiologi RS. Roemani Muhammadiyah Semarang diukur melalui beberapa titik diantaranya :

1. Paparan Radiasi yang Diterima Radiographer

Paparan radiasi ini diukur untuk mengetahui berapa besar radiasi yang diterima oleh radiographer di tempat pekerja saat melakukan ekspose maupun pada saat melayani masyarakat di ruang pelayanan yang diukur pada 2 ruangan yaitu :

a. Paparan radiasi pada ruang operator

Ruang operator berjarak $3 \mathrm{~m}$ dari sumber sinar-X general $\mathrm{X}$-ray, nilai yang terukur adalah $0,0354(\mu \mathrm{Sv} / \mathrm{jam})$. Nilai tersebut jauh dari nilai batas dosis yang ditetapkan, sehingga para pekerja yang menempati ruang operator pada saat melakukan ekspose masih aman, karena nilai tersebut masih jauh di bawah nilai batas dosis yang telah diterapkan oleh Perka BAPETEN. Hasil pengukuran paparan radiasi pada ruang operator ditunjukkan oleh tabel berikut :

Tabel 1. Hasil pengukuran paparan radiasi di Ruang Operator

\begin{tabular}{|c|c|c|c|c|}
\hline No & $\begin{array}{c}\text { Jarak } \\
\text { dari } \\
\text { sumber }\end{array}$ & $\begin{array}{l}\text { Data } \\
\text { ke- }\end{array}$ & $\begin{array}{c}\text { Jumlah } \\
\text { paparan } \\
\text { radiasi } \\
(\mu \mathrm{Sv} / \text { jam }) \mathrm{x} \\
\text { Faktor } \\
\text { Kalibrasi } \\
(1.04) \\
\end{array}$ & $\begin{array}{c}\text { Hasil } \\
\text { terukur } \\
(\mu \mathrm{Sv} / \mathrm{jam})\end{array}$ \\
\hline 1 & \multirow{5}{*}{3 meter } & 1 & 0.0416 & \multirow{5}{*}{0.0354} \\
\hline 2 & & 2 & 0.0312 & \\
\hline 3 & & 3 & 0.0416 & \\
\hline 4 & & 4 & 0.0416 & \\
\hline 5 & & 5 & 0.0208 & \\
\hline
\end{tabular}

b. Paparan radiasi pada ruang pelayanan

Ruang pelayanan berjarak $7 \mathrm{~m}$ dari sumber sinar-X general X-ray, nilai yang terukur adalah 0 atau tidak terukur nilai paparan radiasinya saat dilakukan ekspose. Hal tersebut dapat terjadi karena jarak yang cukup jauh dari sinar-X, selain jarak yang jauh ruang pelayanan juga terhalang oleh pintu dan tembok ruang general X-ray dilapisi oleh timbal serta pintu ruangan yang selalu tertutup. dari hasil tersebut dapat dinyatakan bahwa pada koridor karyawan aman 
dari paparan radiasi. Hasil pengukuran paparan radiasi pada ruang penelitian ditunjukkan oleh tabel berikut:

Tabel 2 Hasil pengukuran paparan radiasi pada ruang pelayanan

\begin{tabular}{ccccc}
\hline No & $\begin{array}{c}\text { Jumlah } \\
\text { paparan } \\
\text { dari } \\
\text { radiasi } \\
\text { sumber }\end{array}$ & $\begin{array}{c}\text { Data } \\
\text { ke- }\end{array}$ & $\begin{array}{c}\text { Hasil } \\
(\mu \text { Sv/jam }) x \\
\text { Faktor } \\
\text { Kalibrasi } \\
\text { terukur } \\
(\mu S v / j a m)\end{array}$ \\
\hline 1 & & 1 & 0 & \\
2 & & 2 & 0 & 0 \\
3 & 7 meter & 3 & 0 & \\
4 & & 4 & 0 & \\
5 & & 5 & 0 & \\
\hline
\end{tabular}

2. Paparan radiasi yang diterima oleh masyarakat sekitar ruang radiologi

Paparan radiasi ini diukur untuk mengetahui seberapa besar paparan radiasi yang diterima oleh masyarakat sekitar ruang radiologi yang berada di ruang tunggu. Hasil dari kedua pengukuran menunjukkan bahwa paparan radiasi yang diterima oleh masyarakat dalam kondisi aman karena paparan radiasi diserap baik oleh timbal yang ada di sekitar ruangan general X-ray II dan pintu-pintu selalu tertutup dengan rapat sehingga kemungkinan untuk lolosnya radiasi sangat sedikit. Hasil pengukuran paparan radiasi yang diterima oleh masyarakat umum ditunjukkan pada tabel sebagai berikut:

Tabel 3 hasil pengukuran paparan radiasi yang diterima oleh masyarakat pada jarak 3,5 m

\begin{tabular}{|c|c|c|c|c|}
\hline No & $\begin{array}{c}\text { Jarak } \\
\text { dari } \\
\text { sumber }\end{array}$ & $\begin{array}{c}\text { Data } \\
\text { ke- }\end{array}$ & 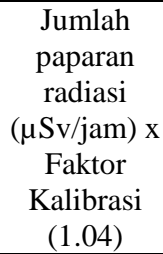 & $\begin{array}{c}\text { Hasil } \\
\text { terukur } \\
(\mu \mathrm{Sv} / \mathrm{jam})\end{array}$ \\
\hline 1 & \multirow{5}{*}{$\begin{array}{c}3,5 \\
\text { meter }\end{array}$} & 1 & 0.0104 & \multirow{5}{*}{0.0146} \\
\hline 2 & & 2 & 0.0104 & \\
\hline 3 & & 3 & 0.0208 & \\
\hline 4 & & 4 & 0.0104 & \\
\hline 5 & & 5 & 0.0208 & \\
\hline
\end{tabular}

Tabel 4. hasil pengukuran paparan radiasi yang diterima oleh masyarakat pada jarak $8 \mathrm{~m}$

\begin{tabular}{|c|c|c|c|c|}
\hline No & $\begin{array}{c}\text { Jarak } \\
\text { dari } \\
\text { sumber }\end{array}$ & $\begin{array}{c}\text { Data } \\
\text { ke- }\end{array}$ & $\begin{array}{c}\text { Jumlah } \\
\text { paparan } \\
\text { radiasi } \\
(\mu \mathrm{Sv} / \text { jam }) \mathrm{x} \\
\text { Faktor } \\
\text { Kalibrasi } \\
(1.04) \\
\end{array}$ & $\begin{array}{c}\text { Hasil } \\
\text { terukur } \\
(\mu \mathrm{S} v / \mathrm{jam})\end{array}$ \\
\hline 1 & & 1 & 0 & \\
\hline 2 & & 2 & 0 & \\
\hline 3 & 8 meter & 3 & 0 & 0 \\
\hline 4 & & 4 & 0 & \\
\hline 5 & & 5 & 0 & \\
\hline
\end{tabular}

3. Efektivitas proteksi radiasi

Efektivitas proteksi radiasi sebagai acuan untuk mengetahui seberapa besar atau seberapa efektif proteksi radiasi pada instalasi radiologi.

a. Efektivitas proteksi radiasi pada ruang operator Dosis radiasi pada ruang operator telah diukur dengan jarak $3 \mathrm{~m}$ dari sumber sinar-X, untuk mengetahui nilai efektivitas proteksi radiasi pada ruang operator. Pengukuran dilakukan menghasilkan dua dosis yaitu dosis awal yakni di mana radiasi belum menembus proteksi radiasi dan dosis akhir yakni radiasi sudah menembus proteksi radiasi. Hasil perhitungan efektivitas proteksi radiasi pada ruang operator tabel 4.5 nilai yang dihasilkan cukup besar yaitu $83.33 \%$. Hal ini berarti bahwa proteksi radiasi pada ruang operator cukup aman, karena proteksi yang dapat menyerap radiasi dengan baik. Hasil pengukuran efektivitas proteksi radiasi dapat dilihat pada tabel berikut.

Tabel 5 hasil pengukuran efektivitas proteksi radiasi pada

\begin{tabular}{|c|c|c|c|c|c|}
\hline No & $\begin{array}{c}\text { Jarak } \\
\text { dari } \\
\text { sumber }\end{array}$ & $\begin{array}{l}\text { Data } \\
\text { ke- }\end{array}$ & $\begin{array}{c}\text { Dosis } \\
\text { awal } \\
(\mu \mathrm{Sv} / \mathrm{jam}) \\
\text { x Faktor } \\
\text { Kalibrasi } \\
(1.04)\end{array}$ & $\begin{array}{c}\begin{array}{c}\text { Dosis } \\
\text { akhir } \\
(\mu \mathrm{Sv} / \mathrm{jam})\end{array} \\
\text { x Faktor } \\
\text { Kalibrasi } \\
(1.04)\end{array}$ & $\begin{array}{c}\text { Efektivitas } \\
(\%)\end{array}$ \\
\hline 1 & \multirow{5}{*}{$\begin{array}{c}3 \\
\text { meter }\end{array}$} & 1 & 0.0936 & 0.0104 & \multirow{5}{*}{83,33} \\
\hline 2 & & 2 & 0.0832 & 0.0104 & \\
\hline 3 & & 3 & 0.0936 & 0.0208 & \\
\hline 4 & & 4 & 0.0736 & 0.0104 & \\
\hline 5 & & 5 & 0.0936 & 0.0208 & \\
\hline
\end{tabular}


b. Efektivitas proteksi radiasi pada pintu ruang general X-ray II

Dosis radiasi pada pintu ruang general X-ray II telah diukur dengan jarak 2,5 m dari sumber sinar-X, untuk mengetahui nilai efektivitas proteksi radiasi pada pintu. Pengukuran dilakukan menghasilkan dua dosis yaitu dosis awal yakni di titik pintu ruang general X-ray dan dosis akhir yakni di titik pintu luar ruang general $\mathrm{X}$-ray. Hasil perhitungan efektivitas proteksi radiasi pada pintu ruang general X-ray II dapat dilihat pada tabel 4.6 nilai yang dihasilkan cukup besar yaitu $84.09 \%$. Hal ini berarti bahwa proteksi radiasi pada pintu ruang general X-ray II cukup aman, karena proteksi yang ada dapat menyerap radiasi dengan baik. Hasil pengukuran efektivitas proteksi radiasi dapat dilihat pada tabel berikut :

Tabel 6. hasil pengukuran efektivitas proteksi radiasi pada

\begin{tabular}{|c|c|c|c|c|c|}
\hline No & $\begin{array}{c}\text { Jarak } \\
\text { dari } \\
\text { sumber }\end{array}$ & $\begin{array}{c}\text { Data } \\
\text { ke- }\end{array}$ & $\begin{array}{c}\text { Dosis } \\
\text { awal } \\
(\mu \mathrm{Sv} / \mathrm{jam}) \\
\text { x Faktor } \\
\text { Kalibrasi } \\
(1.04)\end{array}$ & $\begin{array}{c}\begin{array}{c}\text { Dosis } \\
\text { akhir } \\
(\mu \mathrm{Sv} / \mathrm{jam})\end{array} \\
\text { x Faktor } \\
\text { Kalibrasi } \\
(1.04)\end{array}$ & $\begin{array}{c}\text { Efektivitas } \\
(\%)\end{array}$ \\
\hline 1 & \multirow{5}{*}{$\begin{array}{c}2,5 \\
\text { meter }\end{array}$} & 1 & 0.0936 & 0.0104 & \multirow{5}{*}{84.09} \\
\hline 2 & & 2 & 0.0832 & 0.0208 & \\
\hline 3 & & 3 & 0.0936 & 0.0104 & \\
\hline 4 & & 4 & 0.104 & 0.0208 & \\
\hline 5 & & 5 & 0.0832 & 0.0104 & \\
\hline
\end{tabular}

4. Pola sebaran paparan radiasi di ruang general Xray II

Pengukuran paparan radiasi juga dilakukan di dalam ruang general X-ray II, dimana pengukuran dilakukan untuk mengetahui pola persebaran radiasi yang ada di dalam ruang general X-ray, dengan cara melihat langsung pola distribusi kemudian menginterpolasikan data-data pengukuran diseluruh ruang general X-ray II yang diambil beberapa titik berbeda. Hasil pengukuran paparan radiasi dibuat dalam kontur permukaan 3D mengunakan Software Scilab dengan melakukan interpolasi hasil survei.

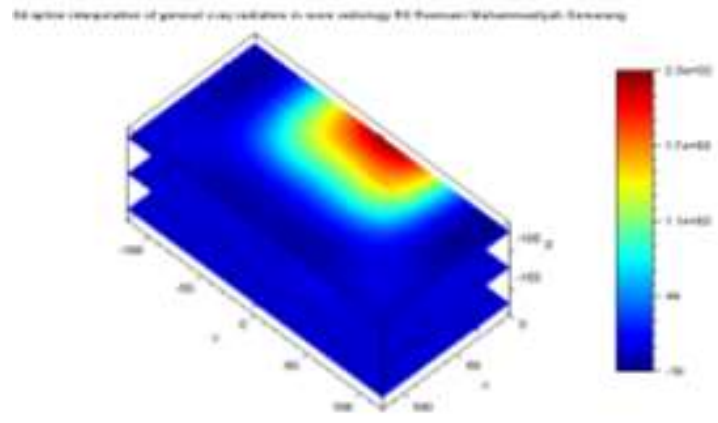

Gambar 7. Hasil kontur 3D pola persebaran radiasi di ruang general X-ray II ebox 120

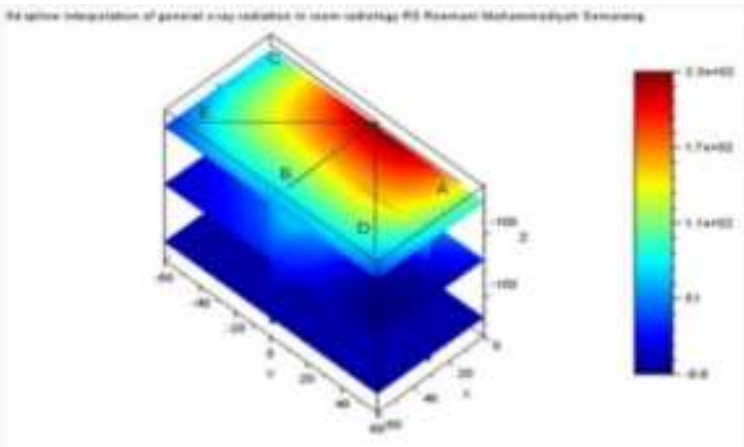

Gambar 8. Hasil kontur 3D pola persebaran radiasi di ruang general X-ray II ebox 60

Berdasarkan hasil interpolasi kontur pemetaan 3D pada gambar 4.1 dan 4.2 dapat dilihat bahwa pada gambar 4.1 dan 4.2 bahwa warna merah tua ke merah menjukkan nilai paparan radiasi yang tinggi sedangkan warna kuning ke hijau menunjukkan nilai paparan radiasi yang sedang dan warna biru muda ke biru tua menunjukkan nilai paparan radiasi yang rendah.

Hal tersebut memperlihatkan bahwa semakin jauh jaraknya dengan sumber radiasi maka nilai paparan radiasi dosis yang terukur akan semakin rendah, sehingga nilai $\mathrm{D} \sim \frac{1}{r^{2}}$ atau dosis yang berbanding terbalik dengan kuadratnya berlaku pada ruang general X-ray II.

\section{Kesimpulan}

Dari hasil yang didapat nilai dosis yang diterima oleh radiographer dan masyarakat sekitar ruangan operator sebesar $0.0354 \mu \mathrm{Sv} / \mathrm{jam}$, nilai tersebut jauh di bawah nilai batas dosis yaitu 2.5 $\mu \mathrm{Sv} / \mathrm{jam}$ sehingga masih aman untuk para radiographe dan pada ruangan pelayanan sebesar 0 $\mu \mathrm{Sv} / \mathrm{jam}$, nilai tersebut tidak diketahui karena letak 
ruangan yang jauh dari ekspose sehingga ruang pelayanan cukup aman untuk para radiographer. Ini merupakan paparan radiasi yang diterima oleh radiographer. Sedangkan untuk paparan radiasi yang diterima oleh masyarakat sekitar untuk ruang tunggu yang berjarak $3,5 \mathrm{~m}$ sebesar $0.0146 \mu \mathrm{Sv} / \mathrm{jam}$, nilai tersebut jauh di bawah nilai batas dosis yaitu 2.5 $\mu$ Sv/jam sehingga masih aman untuk masyarakat yang sedang menunggu pasien dalam melaksanakan pemeriksaan dan pada ruang tunggu berjarak $8 \mathrm{~m}$ sebesar $0 \mu \mathrm{Sv} / \mathrm{jam}$, nilai tersebut tidak diketahui karena letak ruang tunggu yang jauh dari ekspose sehingga ruang tersebut cukup aman untuk masyarakat sekitar.

Dari penelitian ini juga didapatkan nilai efektivitas proteksi radiasi pada ruang operator sebesar $82.05 \%$ sehingga ruangan cukup aman, karena proteksi yang ada dapat menyerap radiasi dengan baik dan pada pintu general X-ray II sebesar $81.08 \%$ sehingga proteksi radiasi pada pintu ruang general X-ray II cukup aman, karena proteksi yang ada dapat menyerap radiasi dengan baik.

Dapat diketahui juga pola sebaran paparan radiasi , semakin jauh jaraknya dengan sumber radiasi maka nilai paparan radiasi dosis yang terukur akan semakin rendah.

\section{Daftar Pustaka}

Ancila, C. Hidayanto, E. 2016. Analisis Dosis Paparan Radiasi pada Instalasi Radiologi Dental Panoramik. Youngster Physics Journal Vol. 5 No. 4, Oktober 2016:441-450.

BATAN, 2005. Keselamatan dan Kesehatan Terhadap Pemanfaatan Radiasi Pengion. Diklat Proteksi Radiasi, Pusat Pendidikan dan Latihan BATAN. Jakarta

Burden R.L, Faires J.D. 2002. Numerical Analysis. Ninth Edition.

Cember Herman. 1983. Pengantar Fisika Kesehatan Edisi Kedua - Telah Direvisi dan Diperluas. IKIP Semarang Press; Pergamon Press.

Daenuri, A. 2011. Sistem Proteksi Radiasi : Analisis Terhadap Bidang Radiologi Rumah Sakit. Jurnal Phenomenon, Volume 1 Nomor 1, Juli 2011.

Dr. Eng. Supriyanto, M.Sc. 2006. Interpolasi Cubic Spline. Lab. Komputer, Departemen Fisika, Universitas Indonesia.

Drs. Muklis Akhadi 2000. Dasar-Dasar Proteksi Radiasi. Jakarta: PT. Rineka Cipta.

Gabriel JF. 2005. Fisika Kedokteran. Penerbit Buku Kedokteran. Jakarta: EGC.
Hiswara Eri. 2015. Buku Pintar Proteksi Radiasi dan Keselamatan Radiasi Di Rumah Sakit. BATAN Press.

Kari and Saunamaki. 2010. Radiation Protection in the Catheterization Laboratory. Interventional Journal 2 (5):667-672.

Kementrian Agama RI. 1989. Mushaf Al-Qur'an 30 juz. Bandung: CV. Gama Risalah Faris.

Keputusan Kepala Badan Pengawas Tenaga Nuklir NO. 1 Tahun 1999. Ketentuan keselamatan kerja terhadap radiasi.

Laitabun, Y.M, Heri, S., dan Choirul, A., 2013. Pengukuran laju paparan radiasi sinar-x pada ruang operator RSUD. Prof. Dr. W. Z. Johannes Kupang, Youngster phys ics Juornal, Vol. 2, No. 1, Fisika Undip, hal 49-52.

Martem, D. R. Milvita, D. dkk. 2015. Pengukuran Dosis Radiasi Ruangan Radiologi II Rumah Sakit Gigi dan Mulut (RSGM) Baiturrahman Padang Menggunakan Surveymeter Unfors-XI. Jurnal Fisika Unand Vol. 4 No. 4. Oktober 2015.

Midel Yoel, L. Susanto, H. dan Anam, C. 2013. Pengukuran Laju Paparan Radiasi Sinar-X Pada Ruang Operator RSUD.Prof.DR.W.Z. Johannes Kupang. Youngster Physics Journal, Jurusan Fisika, Fakultas Sains dan Matematika, Universitas Diponegoro, Semarang.

Nuzula, I. R. 2016. Kajian dan Analisis Pelat Timbal (Pb) Bekas Tutup Instalasi pada Atap Rumah sebagai Bahan Proteksi Radiasi Sinar-X. Skripsi Universitas Negeri Semarang.

Raudhah, U. 2008. Distribusi Terimaan Dosis Radiasi Pada Kegiatan Radiografi Dental Anak. Skripsi Fakultas Matematika dan Ilmu Pengetahuan Alam. Universitas Andalas Padang.

Rudi, Pratiwi dan Susilo. 2012. Pengukuran Paparan Radiasi Pesawat Sinar-X Di Instalasi Radiodiagnostik Untuk Proteksi Radiasi. Jurnal Fisika FMIPA Universitas Negeri Semarang Gunungpati, Semarang. Jawa Tengah.

Sahid. 2005. Pengantar Komputasi Numerik dengan MATLAB. Universitas Negeri Yogyakarta: Andi Yogyakarta.

Setiawan Rudi. 2012. Pengukuran Paparan Radiasi Pesawat Sinar- $X$ di Instalasi Radiologi Radiodiagnostik Untuk Proteksi Radiasi. STIKES An-Naser Kaliwades, Sumber, Cirebon Jawa Barat Indonesia.

Williams, J. R. Montgomery, A. 2000. Measurements of Dose in Panoramic Dental Radiology. The British Journal of Radiology. 73(2000). 1002-1006.

http://gradiology.com.au/service/general-x-ray diakses 20 september 2019.

http://www.bing.com/images diakses 20 september 2019. 